\title{
Derrida's The Purveyor of Truth and Constitutional Reading
}

\section{Jacques de Ville}

\begin{abstract}
In this article the author explores Jacques Derrida's reading in The Purveyor of Truth of Edgar Allan Poe's The Purloined Letter. In his essay, Derrida proposes a reading which differs markedly from the interpretation proposed by Lacan in his Seminar on 'The Purloined Letter'. To appreciate Derrida's reading, which is not hermeneutic-semantic in nature like that of Lacan, it is necessary to look at the relation of Derrida's essay to his other texts on psychoanalysis, more specifically insofar as the Freudian death drive is concerned. The present article explores this 'notion' as elaborated on by Freud in Beyond the Pleasure Principle as well as Derrida's reading of this text. It also investigates the importance of the 'notion' of the death drive as well as the significance of Derrida's reading of The Purloined Letter for constitutional interpretation.
\end{abstract}

The hermeneutic compulsion: that is what superstition and 'normal' psychoanalysis have in common, and Freud says so very plainly [en toutes lettres].

Derrida [1, p. 367]

\section{$1 \quad$ Introduction}

In The Purveyor of Truth, Derrida [2, 3] provides a very different reading from that of Lacan [4] in his Seminars (1955-1957) of Edgar Allan Poe's The Purloined Letter (1845 [5]). Derrida's The Purveyor of Truth has thus far found little favour with scholars. Many scholars, following what has become known as the 'classic' reading of Johnson [6], in analysing or referring to these texts, have assumed that Derrida's reading, like that of Lacan, is concerned with finding the 'meaning' of The Purloined Letter or have chosen to focus on the alleged 'rivalry' between Lacan and Derrida, and for this reason have tended to dismiss or deride Derrida's reading [7, pp. 64-66; 8, pp. 1171-1180; 9; 10; 11, pp. 154-157; 12; 13, pp. 218-223; 14, pp. 51-71; 15, pp. 9-14; 16, pp. 190-195]. In the few instances in which The Purloined Letter has received attention in the legal context, Lacan's reading has mostly been chosen for analysis rather than that of Derrida $[17 ; 18$, pp. 51-53, 62-63; 19; 20, pp. 673-674; 21, pp. 764-775]. A commentary on Johnson's reading by Derrida [2, pp. 148-152] in the letter of 20 June 1978, shows his despair at being misread even by those who have translated his work. These comments of Derrida indicate that 'something more' is at stake in The Purveyor of Truth than at first meets the eye. The temptation to be harsh in evaluating Johnson's essay and those following in her step should nevertheless be resisted. Not only is Derrida's text an extremely complex one, even more so than that of Lacan, but the Johnson essay was published before the re-publication of The Purveyor of Truth in The Post Card: From Socrates to Freud and Beyond, which has made it easier to understand the context of Derrida's essay. The contention in the present article is that an exploration of the 'something more' in The Purveyor of 
Truth must proceed through a reading of the other essays collated in The Post Card, and certain of Derrida's other texts, especially those on psychoanalysis. What becomes clear from a reading of these texts is that in The Purveyor of Truth Derrida is not simply concerned with proposing a 'better' reading-than that of Lacan-of The Purloined Letter, but more importantly with the economy of the death drive and the influence that this has on psychoanalysis and the reading of texts. Different from that of Lacan, Derrida's reading of The Purloined Letter is not hermeneutic-semantic in nature [2, p. 432]. The present article will explore the reason for the differences between Derrida's and Lacan's readings of The Purloined Letter through an analysis of primarily Derrida's text. ${ }^{1}$ The emphasis will thus be on Derrida's reading which will be explored within the broader context of his thinking on psychoanalysis. Lacanian thinking, restricted primarily to the time of the Écrits, will be elaborated upon only in order to place Derrida's reading within context.

Derrida's reading of The Purloined Letter, it will be contended here, is of great importance for constitutional interpretation. Contemporary approaches to constitutional interpretation can be said to be divided between those which are based on the idea that meaning is generated by the intention of the author and those which accord some role to the interpreter of the text and/or to the existing context in the generation of meaning. With respect to the latter approaches, they furthermore diverge between those which seek to hold the interpreter to more or less strict substantive and/or procedural criteria [25-28] and those which accord to the interpreter or to interpretive communities the primary role and responsibility in textual interpretation $[29,30]$. The above approaches to interpretation in general accord very little if any importance to psychoanalytic theory. Where psychoanalytic theory is taken account of in approaches to interpretation, Freud and/or Lacan, at times also in combination with Derrida, are usually the bases for such analyses. ${ }^{2}$ These approaches tend to posit a relation between law and justice where the latter is understood with reference to Oedipal desire [32, pp. 9-25; 33, pp. 297-369; 34, pp. 1-107]. The importance of Derrida's The Purveyor of Truth lies in its exploration of an approach to reading which goes beyond the Oedipus complex and therefore also beyond a hermeneutic-semantic approach, whilst relying on some of the key insights of Freud and which can at the same time be extended to constitutional reading. Although Derrida's texts are frequently invoked in proposing alternative approaches to constitutional interpretation, these approaches generally do not take adequate account of Derrida's relation to psychoanalysis (and where it is touched upon, do not always show an adequate appreciation of the differences between Derrida's approach and that of Lacan). This almost inevitably leads to a moderation of the implications of Derrida's thinking for constitutional reading. Through a detailed analysis of the thinking that informs Derrida's approach to reading in The Purveyor of Truth in this article and by pointing to the profound differences between his reading and that of

\footnotetext{
${ }^{1}$ The present article ties in with, but also differs in a number of respects from the more favourable evaluation of The Purveyor of Truth by Norris [22, pp. 113-117], Major [23] and Hobson [24, pp. 173-177].

${ }^{2}$ Cornell [31, pp. 112-115, 143] read with 85-89 and 172-183 could however be said to seek to follow Derrida rather than Lacan or Freud.
} 
Lacan, some of the implications for constitutional interpretation will be spelled out in the concluding section. 3

\section{The Purloined Letter}

The story as told by Poe starts with two friends (the narrator and Dupin) who are joined in the library of Dupin by the Prefect of Police. The Prefect tells them of the theft of a letter. The Queen of France, having received a letter, possibly from a lover or a (co-)conspirator, is surprised in her private chambers by the King. She does not have time to hide the letter and therefore places it on a table. They are in turn joined by a Minister (D), who notices the Queen's embarrassment, as well as the cause for it. Knowing that she cannot draw attention to the letter for fear of the King finding out about it, the Minister takes the letter before her eyes-the King not noticing anything-and replaces it by a similar-looking letter. The identity of the thief is thus known, but the Prefect, having secretly searched the premises of the Minister in his absence for the past 3 months, has been unable to find the letter. The Minister, in the meantime, has been using the letter to blackmail the Queen. Dupin, who has shown himself to be an acute observer and solver of crimes in two previously recounted stories by Poe (The Murders in the Rue Morgue and The Mystery of Marie Roget) visits the Minister in his apartment, sees the letter (in slightly altered form) hanging openly on a pasteboard card-rack. It appears that the Prefect and his team looked for the letter in its original form only and on the assumption that it would be hidden, and therefore were unable to find it. The next day, Dupin visits again to collect his intentionally-left-behind snuff-box, having also arranged for a disturbance caused by a 'mad-man' outside, which distracts the Minister and thus giving Dupin an opportunity to take the letter and to replace it by a replica. He leaves a note making it clear to the Minister that he (Dupin) had taken it, in return for a misdeed by the Minister against him (Dupin) some time ago. The inscription alludes to the myth of the brothers Atreus and Thyestes, the latter having committed adultery with Atreus's wife, with Atreus in revenge killing Thyestes's sons and serving them to Thyestes at a banquet.4 Dupin, in return for a monetary award, gives the letter to the Prefect who returns the letter to the Queen. Dupin's calculation is that the Minister, not realizing that the letter has been taken from his apartment, will continue with his blackmail of the Queen, this inevitably leading, in the changed circumstances, to his downfall.

\section{Lacan's Seminar on The Purloined Letter}

In The Purveyor of Truth, Derrida [2, pp. 424, 425] compliments Lacan's reading in the Seminar on 'The Purloined Letter' (hereafter, the Seminar) because of the advancement made there in the context of 'psychoanalytically' reading literature (see also Derrida [38, pp. 91-92 n. 44]). Lacan's focus is not on the intention or

\footnotetext{
3 There are of course different ways in which the implications of Derrida's thinking for constitutional interpretation can be explored, e.g. through a careful reading of Declarations of Independence in Derrida [35, pp. 46-54] and/or of Derrida [36]. For reasons of space this analysis cannot be undertaken here.

${ }^{4}$ See also Derrida [37]. In some versions of this myth only one son (Plisthenes) is referred to.
} 
psychological make-up of the author (as for example that of Bonaparte [39, 40], but on the text and the function of the signifier [2, pp. 420,424]. Elsewhere, Derrida has similarly praised Lacan for his renewal of Freudian thought [41, p. 186]. Derrida nevertheless focuses on other aspects of Freud's texts, which do not share the same metaphysical assumptions as those elaborated on by Lacan, at least in the Seminar [41, pp. 171-173]. In The Purveyor of Truth, Derrida [2, pp. 425-427] furthermore takes issue with Lacan because of the latter's reliance on the 'story' to bring out or illustrate the 'truth' which according to Lacan [4, p. 7] makes the existence of fiction possible. The Lacanian truth is in the Seminar closely connected to castration, the phallus, the signifier, the Oedipus complex, as well as the symbolic and imaginary orders. In the Seminar specifically, which Lacan notes concerns repetition automatism as elaborated on by Freud [42] in Beyond the Pleasure Principle, Lacan appears to focus primarily on the very Oedipal chapter III of Beyond, whereas Derrida, as he usually does, relies at least partly on the heterogeneity of this text of Freud in his reading of The Purloined Letter.

Lacan's reliance on fiction in the Seminar is according to him (Lacan) based on the fact that "the classics [humanités] sketch out the experience of man's relation to the signifier, and it is in this relation that the situations that generate what we call humanity are instituted" [4, p. 375]. Lacan in the Seminar plays with the idea that a 'letter' is not only an epistle but also a typographical character or signifier [2, p. 427; 4 , p. 17; 43, p. 321]. The phallus is for Lacan the primary signifier, with the letter acting as its spokesman. The letter (speech) is in other words the place or the ideal site of the signifier/phallus [2, pp. 477-479; 44, pp. 59-60]. Lacan's focus in the Seminar on what he identifies as two triangular scenes which are narrated in the course of different dialogues and which are repetitive in terms of the positions the characters take in the scenes, is not only related to the Oedipus complex, but also to speech as well as to his view that the unconscious is structured like a language and that the unconscious is the Other's discourse [4, pp. 10, 436; 45, pp. 71-72). Lacan relies on this structure of The Purloined Letter to illustrate that it is in discourse, speaking, dialogue or intersubjective communication that the Other or the unconscious finds expression [4, p. 30]. Taking account of the importance of the phallus in the resolution of the Oedipus complex in Lacan's model as well as the importance of the symbolic order in this process, the Seminar could also be said to relate to the resolution of this complex and with what is required of a psychoanalyst in assisting an analysand to do so. ${ }^{5}$ In the latter respect, Lacan's dispute with the psychoanalytic community plays an important role in his reading of The Purloined Letter. Lacan for example identifies two Dupins or two types of psychoanalysts: the fool who remains an integral part of the circuit (taking revenge on the Minister) while believing himself to be its master, and another Dupin (representing Lacan) who knows to whom and how the letter needs to be returned [2, pp. 450-452, 455-456].

\footnotetext{
${ }^{5}$ Similar therefore to Freud's reading of The Emperor's New Clothes which is also analysed by Derrida [2, pp. 414-419].
} 
In Lacan's reading, the letter in The Purloined Letter is furthermore not stolen, but simply diverted from its path [4, pp. 20-21]. The diversion of the letter, its nondelivery or sufferance makes those characters in the story who take possession of the letter after the Queen 'lost' it (the Minister, and one of the Dupins) 'suffer' or become 'feminised' in identifying with the Queen [2, pp. 450, 452]. This is because of the power that the imaginary phallus exercises over them through the letter. By possessing the letter they each effectively find themselves in the position of someone attempting to be the missing (imaginary) phallus of the mother (the Queen) in order to satisfy the desire of the mother, instead of accepting their own (symbolic) castration as well as that of the mother. First the Queen, in the first ('primal') scene, then the Minister and (the one) Dupin in the second scene, thus find themselves within the imaginary order [2, pp. 438-439; 4, pp. 21-22]. ${ }^{6}$ This can be understood within the context of Lacan's theory that the child in a successful resolution of the Oedipus complex renounces the aspiration to be the phallus for the mother, leading to his association with the law of the Name-of-the-Father (the symbolic order). It also requires, and here lies the brilliance of Dupin, that the analysand comes to realise through the intervention of the analyst (with speech playing a central role) that the phallus is not something 'real' or an actual object that was lost by the mother, but a signifier.

\section{Derrida's Reading of The Purloined Letter}

As should already be clear, more is at stake in Lacan and Derrida's readings than arbitrary attempts to interpret The Purloined Letter. Both readings are 'psychoanalytical-philosophical', Lacan's more so than that of Derrida, as Derrida's reading goes in some sense 'beyond' both philosophy and psychoanalysis. Derrida's The Purveyor of Truth furthermore does not seek to show that Lacan's reading is wrong. As Derrida would confirm in a later text, he actually says in The Purveyor of Truth that Lacan is correct in his reading as concerns reason and the masculine nature of the libido [2, pp. 482-483; 44, pp. 62-63].7 Derrida also does not seek to criticise Lacan's reading in the traditional sense [2, p. 483; 44, p. 63]. The Purveyor of Truth should instead be read as seeking the conditions of possibility and therefore also as seeking to displace or resituate Lacan's phallogocentric reading of The Purloined Letter and of his psychoanalytical-philosophical approach. Derrida is not saying that his reading is the only reading of the 'story', but his reading is the reading that shows what makes its telling as well as readings thereof possible.

Derrida [2, pp. 428, 461], in his reading, contends that the dialogic scenes that Lacan sees in The Purloined Letter are framed, which leads to a complication in Lacan's attempts to control its meaning ("the castration of the mother as the ultimate

\footnotetext{
${ }^{6}$ The imaginary according to Lacan is formed during the mirror stage (6-18 months) where the child is captured by his own self-image (seen in a reflective surface or in the reflection provided by another person) as yet unaware of the symbolic order of which he is a part; see Lacan [4, pp. 75-76] and Muller and Richardson [45, p. 61].

${ }^{7}$ See also Lacan $[4$, p. 584] and Ragland-Sullivan [46, p. 289] on the androcentric nature of culture.
} 
meaning and proper site of the letter"). In Lacan's account there are two neutralisations-of the narrator and of the textual fiction. Derrida contends that by focusing only on the two triangular scenes, as Lacan does, one misses the position of the narrator, and in doing so, one omits everything in the scene of writing that overflows the two Oedipal triangles [2, pp. 428-431, 483]. The narrator is not simply a neutral and transparent reporter as Lacan makes him out to be, but someone who from the moment of meeting Dupin intervenes in the narration [2, p. 429, 486]. The narrator is always a fourth character in the triangular scenes described by Lacan. The narrator not only narrates, but is himself put onstage; he in other words intervenes in these scenes as narrator and also as stage director [2, pp. 428-430]. As Derrida puts it, the narrator narrates himself and "puts himself forward as a very singular character within the narrated narration, within the enframed" [2, pp. 431, 433]. Already in the "simulacrum of an opening" the narrator narrates to himself "several propositions which engage the unity of the 'tale' in an interminable drift" [2, p. 483].

Lacan's Seminar, Derrida points out, takes no account of this drift [2, p. 483]. The tale furthermore starts 'in' a library, and thus with books and writing [2, pp. 484485]. "Therefore nothing begins", Derrida points out, "[o]nly a drifting or disorientation from which one does not emerge" [2, p. 484]. One could also say, as Derrida [1, p. 127] does in Envoi where he refers to The Purloined Letter, that everything begins by referring back and therefore does not begin. Reference is also made in the opening paragraph of The Purloined Letter to the two earlier Dupin mysteries, to silence, smoke, and darkness [2, p. 484]. The hermeneut, who is interested only in the meaning or the centre of the picture, will see little relevance in this, regarding it as the mere ornamental frame of a narrative, Derrida notes [2, p. 484]. Derrida also stresses the reference to coincidence and events of chance in the opening paragraph of The Purloined Letter, referring to its occurrence in The Murders in the Rue Morgue where it is recounted that the first meeting between the (narrating-narrated) narrator and Dupin had taken place in an "obscure library", this time in the Rue Montmartre, where both were coincidentally searching for "the same very rare and remarkable volume" [2, p. 485]. The same 'theme' of coincidence is also referred to towards the end of The Mystery of Marie Roget, something that Derrida [1, pp. 344-376; 47, pp. 1-32] will take up again in My Chances (see also Derrida [48, pp. 330, 437 n. 19, 339, 346]). Derrida furthermore refers to the epigraph to The Murders in the Rue Morgue (pointing inter alia to the possible name Achilles assumed when he hid himself among women) and the 'preface' (containing reflections on the skills of an analyst, also in playing games) that one finds here which precedes the first meeting between Dupin and the narrator. The introduction to Dupin, which the narrator provides, includes an explanation of his unfortunate financial position (left only with a small remnant of his paternal inheritance) and a reference to something which exceeds the strict economy he has to impose on himself, like a gift without return: the luxury of books, which Dupin allows himself. The notion of luxury will return in the introductory paragraph of The Purloined Letter in the (two-fold)

\footnotetext{
${ }^{8}$ Derrida's argument in The Purveyor of Truth is itself set adrift in The Post Card; see Derrida [44, p. 63].
} 
form of meditation and meerschaum [2, p. 487]. Between the narrator and Dupin, a financial relation is furthermore established in terms of which Dupin provides the narrator with "priceless writing" and the narrator provides for Dupin, the analyst financially, also in the form of accommodation. The narrator in other words pays (Dupin) in order to write or speak and he also makes Dupin speak. This shows the involvement and participation

in the narration of the narrator, making it impossible for him to be a simple neutral observer and narrator of Oedipal triangles. The narrator also rents an old house where no one can find them (the narrator and Dupin) where the two of them live like madmen in secret and in the dark of night (actual and feigned) whence the narrator narrates his progressive identification with Dupin [2, pp. 489-490].

Insofar as the textual fiction which frames the narration is concerned, Derrida draws a distinction between the author and his actions; the inscriber (the scriptor-fictor) and the inscribing (the scription-fiction named The Purloined Letter); the narrator and his narrating; and the narrated content [2, pp. 430-432]. We should furthermore not confuse the fiction with the narration as Lacan does, Derrida notes [2, p. 431]. This frame around the narration begins not only with the first letter of the title, the epigraph from Seneca, or with "At Paris after dark" [2, p. 431]. Paying attention to the frame surrounding the triangles has important implications for the

Oedipal structure [2, p. 433]. This is where Derrida introduces dissemination, which leaves no place for the lack or where the lack has no place [2, p. 441]. For Derrida the purloined letter has no fixed location, not even a definable hole or assignable lack [2, p. 442]. It is also not to be found in the 'story', but rather 'in' the text, understood here in a broad sense as the very open letter that is fiction [2, pp. 442, 443]. The purloined letter, one could also say, is in the text; not simply as an object, contained in the text with a fixed destination, but "also as the text producing the effects of the frame" [2, p. 443]. This implies a self-divesting fourth agency "which at the same time divests the letter of the text from whoever deciphers it, from the facteur of truth [that is, Lacan9] who puts the letter back into the circle of its own, proper itinerary" [2, p. 443].10 Contrary to Lacan's claim that a letter always arrives at its destination, Derrida contends that the letter, because of its divisibility, can always not arrive at its destination [2, pp. 444, 464]. This easily misapprehended contention will be explored in more detail below. It will suffice for now to note that this is not a reference to postal letters, at least not in the ordinary sense.

Derrida agrees with Lacan that The Purloined Letter "demonstrates ... the crushing repetition compulsion" [2, pp. 457-458]. Lacan and Bonaparte both read The Purloined Letter in this way. Bonaparte, different from Lacan, however places The Purloined Letter within a broader textual network, referring to similar motifs, for example the fireplace, in Poe's The Murders in the Rue Morgue, which also involves

\footnotetext{
${ }^{9}$ See Derrida [2, p. 373] on the facteur: "the postman, of a narrative that he transmits by maintaining what is 'essential' in it: underlined, cut out, translated, commented, edited, taught, reset in a chosen perspective'".

${ }^{10}$ Freud, Derrida, contends, was more careful than Lacan in grounding fiction in truth by indicating that literary fiction always resists the general law of psychological knowledge; see Derrida [2, pp. 426-427].
} 
Dupin. The Purloined Letter, as pointed out above, furthermore forms part of a trilogy, which includes also The Mystery of Marie Roget. The title itself-The Purloined Letter-appears to refer to an object within the text, but actually refers to the text and to itself as having been purloined, dispossessed, disseminated in advance and thus evading every assignable destination [2, p. 493]. ${ }^{11}$ It is interesting, Derrida points out, that Lacan mentions nothing about the broader textual network in his Seminar. Lacan not only lifts two (triangular) dialogues out of The Purloined Letter and focuses his analysis on them, but he also excludes the rest of the Dupin trilogy in his analysis [2, p. 459]. Derrida turns here, with reference to Bonaparte, to the motif of the double ${ }^{12}$ in The Purloined Letter which Lacan attempts to exclude or marginalise in his analysis [2, pp. 459-46o]. This exclusion or neutralising of the double by Lacan, Derrida contends, is performed in order to avoid "uncontrollable anxiety" [2, pp. 460-461]. Derrida points out, as indicated above, that the narrator is himself double, telling the story, and being told of (narrator-narrated) [2, p. 460]. Dupin is also double; he is in a sense the double of a double (the narrator) [2, p. 460]. In other words, he is also outside of the triads just like the narrator is inside what he narrates [2, p. 490]. The Minister is similarly double: both poet and mathematician [2, p. 492]. The relation between the doubles (which Lacan would reduce to the imaginary), Derrida contends, "includes and envelops the entire space said to be of the symbolic, overflows and simulates it, ceaselessly ruining and disorganising it" [2, pp. 491-492].13 The same effect is produced through the copy of the outside of the letter Dupin uses as a replacement which mentions the story of the two brothers Atreus and Thyestes who are not part of the symbolic (mother-father-child) family triangle [2, p. 492].

\section{$5 \quad$ Explicating Derrida's Reading}

A number of questions could still be raised after the above exposition, such as: What would 'justify' adopting Derrida's reading rather than that of Lacan? Why does Derrida find it necessary to emphasise the double function of the narrator and some of the other characters in The Purloined Letter? Why does he emphasise framing and the drifting effect this apparently leads to? Is there any significance in the position Derrida takes regarding the location and the content of the letter? How could Derrida possibly say that the condition of possibility of a letter is that it is capable of not arriving at its destination? In order to answer these questions and to appreciate Derrida's reading, one has to have an understanding of his thinking in relation to language and psychoanalysis. This cannot proceed without an analysis of his contemplations on the death drive in reading Freud's Beyond the Pleasure Principle. This text plays a central role in Derrida's reflections on psychoanalysis,

\footnotetext{
${ }^{11}$ See also Derrida [49, p. 32] on flowers which are constantly being stolen.

${ }^{12}$ Derrida draws here on Freud's essay "The Uncanny" in Freud [50, pp. 217-256] and his own further explorations of the double in "The Double Session", in Derrida [51, pp. 187-316].

${ }^{13}$ In Derrida [52, pp. 121-146] the distinction between the symbolic and the imaginary is further complicated.
} 
not only in The Post Card, but in many other texts as well $[44 ; 48$, pp. 246-291; 51, pp. 187-316; 53].

Lacan has of course done much to show the importance of language for psychoanalysis. At least at the time of the Écrits, the view of language that Lacan adopts however remains linked to the values traditionally privileged by philosophy: speech, presence, truth and intention. Lacan specifically continues to rely on the problematic notion of the sign, in which access of the signifier to the signified is barred; and where the signifier is the symbol of an absence [4, p. 17]. For Lacan, signifiers are indivisible and find their ultimate meaning (signified or transcendental signifier) in the structure of the unconscious. This is the location from which they are 'sent' or 'posted' and to which they must be returned by the psychoanalyst. In his reading Derrida seeks to show that the unconscious generated by the restricted economy of the Oedipus complex is inscribed within what can be referred to as a 'general economy' [2, p. 441; 48, pp. 317-350]. This requires that the unconscious be rethought, and more specifically that an unanalysed, illegible remainder of the unconscious and its relation to language be pointed to [2, p. 304; 44, pp. 1-38; 54]. We will not have space here to discuss in any detail Derrida's thinking in relation to language. It is nonetheless important to note that Derrida adopts a very different reading than Lacan of De Saussure and that the relation of language with death, as its condition of possibility, plays a central role in all of Derrida's reflections on language [38; 51, pp. 67-186; 55-57]. Derrida also departs from the notion of the sign and refers to the mark, as the notion of the sign remains tied to presence and the notion of a final signified [38, pp. 17-22; 56, p. 138]. In The Post Card, through a different reading of Freud, inter alia Freud's Beyond the Pleasure Principle, Derrida [2, pp. 259, 356, 357] similarly contends that a life-death 'stricture' is at work in all organisms. ${ }^{14}$ Understanding the function of this stricture and the role of the death drive (or unconditional pleasure) [2, pp. 398-401] enables a reading of many of the enigmatic passages in The Purveyor of Truth as well as many of Derrida's other texts. ${ }^{15}$ Specifically when Derrida [2, p. 489] notes that the narrator and Dupin are two "madmen speculating", the allusion to Freud's 'mad' speculations ${ }^{16}$ about the death drive can hardly be missed. These speculations, as we know, stemmed from Freud's attempt to find an explanation for his observation that patients tend to repeat unpleasant experiences, for example in analysis and in dreams. Because of this repetition, it appears that psychic life (both conscious and unconscious) no longer takes account of the apparently dominant pleasure principle [2, p. 269]. The question Freud posed to himself was whether there is a beyond to the pleasure principle (PP).

\footnotetext{
${ }^{14}$ Life and death are not opposed in this stricture; see also Derrida [49, p. 79b; 58, p. 97].

${ }^{15}$ See e.g. also Derrida [59, p. 141]: "Both of them [Max and Stirner] love life, which is always the case but never goes without saying for finite beings: they know that life does not go without death, and that death is not beyond, outside of life, unless one inscribes the beyond in the inside, in the essence of the living."

${ }^{16}$ Speculation in Derrida's use of the term has a specific 'meaning'. It involves abandoning oneself, giving oneself over to the totally other; see Derrida [2, pp. 265, 283]. It also does not involve philosophy, or scientific or clinical experimentation in their traditional modes (at 272). It is nevertheless linked to psychoanalytic experience (at 274). Speculation in this 'sense' is not purely or essentially theoretical (at 277), but involves an a-thesis (at 278, 284).
} 
In Beyond the Pleasure Principle Freud 'speculates' that an 'external' force (nature, the system of the earth and the sun) led to a disturbance in inanimate matter, thereby producing life which simply repeats itself and regresses [2, p. 354; 42, p. 38]. According to Freud [42, pp. 38-39] -

[t]he tension which then arose in what had hitherto been an inanimate substance endeavoured to cancel itself out. In this way the first instinct came into being: the instinct to return to the inanimate state. It was still an easy matter at that time for a living substance to die; the course of its life was probably only a brief one, whose direction was determined by the chemical structure of the young life. For a long time, perhaps, living substance was thus being constantly created afresh and easily dying, till decisive external influences altered in such a way as to oblige the still surviving substance to diverge ever more widely from its original course of life and to make ever more complicated détours before reaching its aim of death. These circuitous paths to death, faithfully kept to by the conservative instincts, would thus present us to-day with the picture of the phenomena of life.

Life is in other words a detour which differs/defers not primarily with the aim of pleasure or conservation, but with the aim of death, or a return to the inorganic state [2, p. 354]. ${ }^{17}$ This hypothesis is related to the theory of Hering in terms of which a dualism exists in instinctual life: an assimilatory process and a dis-similatory process, the first being constructive and the latter destructive [58, Vol. 18, p. 49]. It also finds some support in the theories of Helmholz and Breuer concerning a relation between two quantities (bound cathectic energy and freely mobile energy) [2, pp. 28o, 346; 42 , pp. 26-27, 34]. The notion of free, unleashed or unbound energy is referred to by Freud [42, p. 34] as the primary process (pp) [2, p. 344]. Binding of the primary process would occur in the service of the pleasure principle [2, p. 344; 42, p. 62]. Certain drive components which are unbound therefore appear to exist at an interior and archaic or primitive level of psychic organisation having been repressed by the ego [2, pp. 340, 350]. The (dominance of the) pleasure principle would be "a relatively late effect of a history, of an original genesis, a prior victory on a field that does not belong to the PP in advance, and of which the PP is not even a native" [2, p. $350 ; 42$, p. 63]. The tendency to dominance of the pleasure principle consists of a triumph of binding over unbinding, the contra-band over the a-band or the disband, over absolute astricture [2, p. 350]. The binding of the primary process, in other words the binding, mastering or stricturing of the death drive, begins even before the pleasure principle comes into play-it collaborates with the pleasure principle and its delegate the reality principle (PR), but it is not a part of it [2, pp. 351, 393-394; 42, p. $62] .{ }^{18}$ This binding takes place in what can be referred to as a median, differing or

\footnotetext{
${ }^{17}$ This statement should be qualified somewhat in light of Derrida's later analysis which effectively equates the inorganic state with absolute pleasure; see Derrida [2, pp. 398-401]. Absolute pleasure is therefore in a sense equated with absolute unpleasure or pain.

${ }^{18}$ The reality principle could be said to be the representative, slave or informed disciple of the pleasure principle; see Derrida [2, p. 282].
} 
indifferent zone which relates the primary process in its purity to the 'pure' secondary process which is entirely subject to the pleasure principle [2, p. 351].19 In describing this process [2, pp. 393-394] one can see the importance and role of the notion of the supplement in Derrida's thinking:

[T] o bind is immediately to supplement, to substitute, and therefore to represent, to replace, to put an Ersatz in the place of that which the stricture inhibits or forbids. To bind, therefore, is also to detach, to detach a representative, to send it on a mission, to liberate a missive in order to fulfill, at the destination, the destiny of what it represents. A post effect. Of a postman [facteur] charged with proceeding toward delivery. ${ }^{20}$

The secondary process therefore has only a supplementary role in transforming freely mobile cathectic energy into immobile cathectic energy [2, p. 394]. Using the postal metaphor, one could say that the secondary process is the supplementary sending; it posits and it posts [2, p. 394].

The whole operation can be depicted as follows [2, p. 351]:

\section{Pleasure Principle (PP) + Reality Principle (PR) primary process (pp)}

The zone between the two processes, Derrida refers to as the "differantial stricture of a belt" [2, p. 351]. Différance expresses the notion of the binding force or economy through which the death drive limits itself. It also expresses the relation between the pleasure principle and the reality principle, opening the pleasure principle to alterity [2, p. 283]. It is a median, differing and indifferent zone or belt relating the primary process (the death drive) in its 'purity' to the secondary process (subject to the pleasure principle) [2, p. 351]. Différance (or what was referred to above as the divisibility of the letter) ${ }^{21}$ can be said to be the messenger sending letters to the self from the other (death). ${ }^{22}$ The pleasure and reality principles are within this structure or rather 'stricture', "only an internal, secondary, and conditional modification of the absolute and unconditional Umweg" [2, p. 354]. They are firstly in the service of the general Umweg (death). Life is therefore not a question of going towards death, but of leading back to death [2, p. 354]. Death in Freud's analysis, Derrida [2, p. 355] notes, is "inscribed as an internal law [of life], and not as an accident of life". Life is rather an accident of death or an excess of death or as Freud [42, p. 38] puts it, "the aim of all life is death" and "inanimate things existed before living ones" [2, p. 355].

\footnotetext{
${ }^{19}$ See also Derrida [2, p. 396] where he notes that in this zone there is indifference "to pleasure and to unpleasure". However this zone is also "rather interested, inspired, called upon by the PP, since it announces the $\mathrm{PP}$ in its turn and makes room for it'.

${ }^{20}$ See also Derrida [48, p. 266] where he, with reference to Freud, explores a similar originary process at work in dreams.

${ }^{21}$ See Derrida [1, p. 127] on the relation between différance and divisibility.

${ }^{22}$ Similar to some of Derrida's other non-concepts (e.g. pharmakon and hymen) différance gives expression to the life-death stricture which is everywhere in play, rather than to presence.
} 
Nietzsche similarly says, as Derrida [2, pp. 355, 268, 269] points out, that life is a very rare genre of that which is dead and Schopenhauer, that death is the Eigentliche Resultat (real, actual result) and to that extent the purpose of life. Freud nevertheless seeks to deny any debt to Nietzsche, Schopenhauer or to philosophy in general in his speculations on the death drive [2, pp. 264-266].23

The conservative drives or instincts of self-preservation, self-assertion and mastery that motivate recourse to repetitive processes which Freud finds in all that is living must be understood in this context [2, p. 355; 42, p. 39]. These component drives or instincts, Freud [42, pp. 39, 45] asserts, are destined to ensure "that the organism shall follow its own path to death, and to ward off any possible ways of returning to inorganic existence other than those which are immanent in the organism itself", that is, to die of natural causes [2, p. 355]. Paradoxically therefore a living organism struggles most energetically against those events which might make it reach its primary aim most swiftly [42, p. 39]. The non-proper must thus be sent away, the self must be reappropriated, made to come back until death. In the words of Derrida [2, p. 356]:

The organism (or every living organization, every "corpus", every "movement") conserves itself, spares itself, maintains itself via every kind of differentiated relay, intermediary destination, correspondences of short or long term, short or long letters [courrier]. Not in order to keep oneself from death, or to maintain oneself against death, but only in order to avoid a death which would not amount to itself [ne lui reviendrait pas], in order to cut off a death that would not be its own or that of its own. In the detour of the step, in the step of the detour, the organism keeps itself from the other which might steal its death from it. It keeps itself from the other who might give it the death it would not have given to itself by itself (for this is a theory of suicide deferred, or by correspondence), the death that it would not have announced to itself, signified by a sentence, a letter, or a notification that is more or less telegraphic, and of which it would be simultaneously the sender, the receiver, and the transmitter, that is, from one end of the itinerary to the other, and in every sense of the word, the facteur. Addressor and addressee of the news, teleguiding its ... legacy, autoteleguiding it, it ... wishes to toll its own knell, wishes the impossible [footnote omitted].

The conservative drives are therefore the guardians of life, but by the same token ('originally') also the sentinels or satellites of death [2, pp. 82, 360; 42, p. 39]. The same idea can be expressed with reference to the notion of binding, which although it makes room for the pleasure principle, can be said to be ultimately in service of the

\footnotetext{
${ }^{23}$ Derrida explores this denial of debt with reference to the notion of 'envy'. At stake, it appears, is the same jealousy that is evident in the Freudian 'household' (in the analysis of Ernst's fort/da game) between Freud, the husband in law, and Ernst, in relation to Sophie. In Glas, Derrida [49, p. 134b] would contend that the mother always represents death and that "one is always jealous of the mother or of death. Never of a woman or man as such." Freud thus shows the same jealousy in his relation to Nietzsche and Schopenhauer with regard to his speculations on the death drive, as he would show in his relation to Sophie. See further Derrida [53, p. 78] on the jealous violence involved in constituting the self.
} 
most unconditional function-the return to the inorganic state [2, p. 396]. One could also explain this relation between life and death in psychic life with reference to the movement of auto-affection. The self does not exist before all else, before this movement of auto-affection [2, p. 359]. The self can arrive "only by itself differing/deferring itself in (its) totally-other, in a totally-other which should no longer be its own" [2, p. 359]. One could therefore say that an "exappropriation" constitutes the self [2, p. 359]. Another way of explaining this idea would be with reference to the notions of the 'trace' and the 'remainder' [2, p. 358].24 Traces and remainders of the inorganic state have never reached consciousness [2, p. 346]. They are not inscribed in the system perception-consciousness, but in another system, which could be referred to as a psychic aneconomy [2, p. 346; 53, pp. 9-10]. The 'memory' of the return to the inorganic state could also be described as the 'memory' of an original wound, a trauma which had not taken place and which is repressed or as an unanalysed remainder of the unconscious which 'houses' absolute pleasure [2, pp. 304, 362; 54, pp. xx, xlii].25 In recalling oneself to oneself (in appropriating oneself) one is placed in relation to the memory of the original wound. This thinking should not, at least not on Derrida's reading, be equated with a form of biological or psychic determinism. Firstly, it concerns the technical substrates of unconscious memory-the drives being situated at the frontier between the somatic and the psychic [1, p. 123; 60, pp. 121-122; 61, p. 397]. Secondly, as should be clear when Derrida contends that a letter may always not arrive at its destination, this thinking does not give rise to determinacy, but rather to chance or dissemination, the only chance for there to be history, meaning, presence, truth, language etc. [1, p. 128].26

Derrida's athetic reading of Beyond does not seek to prove that there 'is' indeed a beyond to the pleasure principle: the death drive does not exist and does not present itself as such [2, pp. 362, 366]. In seeking to account for Freud's actions in writing Beyond (distancing the pleasure principle, acting as the devil's advocate, but continually returning it to himself as Ernst does with the spool attached to a string), Derrida instead shows that it is a matter of coming back within the pleasure principle [2, pp. 353, 354, 379-380, 395). That which is excluded by Lacan in his reading of The Purloined Letter, is shown by Derrida to be the condition of possibility of the narration. Derrida's analysis of the death drive-which, it should be noted, differs markedly from the Lacanian understanding thereof as expressed in the Écrits, ${ }^{27}$ as

\footnotetext{
${ }^{24}$ This is explored by Derrida [48, p. 289] where the 'notion' of the trace is explained as "the erasure of selfhood, of one's own presence, and is constituted by the threat or anguish of its irremediable disappearance'".

${ }^{25}$ This to be compared with the great trauma of realising the mother's lack of a penis/phallus referred to by Freud, Bonaparte and Lacan; see Derrida [2, p. 445].

${ }^{26}$ There is clearly also a close relation between The Purveyor of Truth and the thinking of Heidegger on the sending of Being, which could be further explored through a reading of inter alia Derrida [62] and Envois, the first chapter in The Post Card; see e.g. Derrida [2, pp. 64-67]. In brief, also with reference to Derrida's other texts on Heidegger, one could say that Derrida's analysis of the Freudian death drive leads to a re-evaluation of the structure of Dasein and also of Being, both being inscribed within différance.

${ }^{27}$ See in this respect Lacan [4, pp. 260-264]: “"TT]he death instinct essentially expresses the limit of the subject's historical function. The limit is death—not as the possible end date of the individual's life, nor as the subject's empirical certainty, but, as Heidegger puts it, as that 'possibility which is the subject's ownmost, which is
} 
well as of those who have adopted the Lacanian understanding of the Freudian death drive in the ethical, political and legal context [64, p. 245; 65, p. 47]-translates into a different role for the Oedipus complex, the castration complex and the role of the 'mother'. The Oedipus complex, Derrida contends, is only one of the possible effects of différance, which would be another name for castration or of Medusa's head, the fear of which causes an erection [2, pp. 340-341; 49, pp. 46a, 59a].28 Linked as death is to différance, castration can also be said to equal death and to be another 'name' for dissemination [49, p. 44a; 51, p. 306 n. 67]. In Lacan's Seminar, we could furthermore say, the mother is the term of a regression, a signified of the last instance [49, p. 116b].29 The 'mother' plays a very different role in Derrida's 'model'. She is the non-place of absolute pleasure (death) and is to be affirmed. In Derrida's texts, the 'mother' could be said to 'stand' for the 'pre-origin' from which we return repeatedly, as the following passages from Glas indicates: "The mother is a thief and a beggar. She appropriates everything, but because she has nothing that is properly hers" [49, p. 150b]. This idea is developed further in some of Derrida's other texts where he refers with approval to the archi-psychoanalytic myth of Imre Hermann (adopted also by Nicholas Abraham) regarding a traumatic archi-event of de-clinging (referring to primates clinging to the fleece of the mother) ${ }^{30}$ which constructs the human topical structure [54, pp. xxxii-xxxiii; 66, p. 6]. This does not seek to privilege the 'natural' mother. The mother is a figure for death, absolute pleasure, the already, ${ }^{11}$ as is the hymen [49, pp. 134b, 136b; 51, pp. 222-223].

\section{The Death Drive and The Purveyor of Truth}

The above analysis assists us in understanding better what is at stake in The Purveyor of Truth, more specifically insofar as the frame, the double, the (posting of) letter(s), as well as the divisibility and fragmentation of the letter are concerned. As should be clear, all of these are related to the 'notions' of dissemination and the death drive and to the life-death stricture that Freud discusses in Beyond. Both in his reading of Beyond and The Purloined Letter, Derrida seeks to affirm absolute pleasure (the death drive) as a 'pre-origin' more 'original' than and independent of the pleasure principle. It is from here (this no-place) ${ }^{32}$ of the diabolical that 'letters' are sent to the self [2, pp. 341-342]:

\footnotetext{
unconditional, unsurpassable, and as such interminable'-the subject being understood as defined by his historicity', (at pp. 261-262); see further Lacan [63, pp. 253-268].

${ }^{28}$ See also Derrida [49, p. 65b] on castrating oneself in writing.

${ }^{29}$ Derrida nevertheless does not here specifically refer to Lacan.

${ }^{30}$ The fleece is in turn closely related to the notion of text; see Derrida [66, pp. 5-6].

${ }^{31}$ See also Derrida [55, pp. 156, 159] where he says that the 'true' or 'natural' mother herself is always already a substitute or supplement; and Derrida [67, pp. 12-13] where he explains why 'woman' plays the important role she does in his texts. This relates to the fact that woman is the excluded other in most cultures and the fact she therefore represents the figure of the absolute other. See further Derrida [49, p.

84bi] where he refers to the already (deja) giving birth to itself (Genet) as a cadaver.

${ }^{32}$ Derrida [2, p. 489] also refers to the secret place whence all letters are sent out as a consequence of two madmen speculating.
} 
The demon is the revenance which repeats its entrance, coming back [revenant] from one knows not where...inherited from one knows not whom, but already persecutory, by means of the simple form of its return, indefatigably repetitive, independent of every apparent desire, automatic...this automaton comes back [revient] without coming back [revenir à] to anyone, it produces effects of ventriloquism without origin, without emission, and without addressee. It is only posted, the post in its "pure" state, a kind of mailman [facteur] without destination. Tele-without telos. Finality without end, the beauty of the devil. It no longer obeys the subject whom it persecutes with its return. It no longer obeys the master, the name of the master being given to the subject constructed according to the economy of the PP, or to the PP it(him)self. Freud insisted upon the passivity, the apparent passivity of the persons thus visited...but also upon the fact that such a demonic visitation is not confined to neurosis.

The Purloined Letter can in a sense be said to show the functioning of memory,33 identity and language. It cannot but speak of the repressed memory or memory trace of a return to the inorganic state, in other words of dissemination, of a loss of meaning, of general writing, that is, of that which 'is' its condition of possibility. As Derrida [2, p. 402] puts it, "[e]very being-together ... begins by binding-itself, by a binding-itself in a differantial relation to itself. It thereby sends and posts itself. Destines itself. Which does not mean: it arrives." Destination, as we saw above, for Derrida, is inextricably tied to death, although not in the Heideggerian (and Lacanian) sense of a mortal being-for-death [2, p. 360; 4, pp. 261-262; 44, pp. 6566). In recalling itself to itself, the self sends away the non-proper; it sends itself letters not to keep itself from death but only in order to avoid a death which would not amount to itself [2, pp. 355, 356]. The self is the sender, the receiver and the transmitter [2, pp. 355, 356]. This is nevertheless a secondary process, a supplementary sending. As the quotation above shows, the letters are firstly sent or posted by the death drive. 34 It is in other words firstly the primary process that sends a postal message in binding or limiting itself from absolute expenditure or free cathectic energy [2, pp. 394, 395]. This is followed by a supplementary sending (post, binding) by the secondary process. Because of this division of the letter, because of this distancing from the self, the risk is there that the letter will not arrive at its destination (the self). 35 The possible non-arrival of the letter (from the self to the self) can nevertheless be said to entail a chance, the mis-address of a chance with the subject no longer being in control [2, pp. 123-124; 44, p. 65]. For Lacan letters are

\footnotetext{
${ }^{33}$ Memory, according to Freud, being the very essence of the psyche; see Derrida [48, p. 252].

${ }^{34}$ See also Derrida [2, p. 12]: 'You give me words, you deliver them, dispensed one by one, my own, while turning them toward yourself and addressing them to yourself'.

${ }^{35}$ This corresponds with what Derrida [2, pp. 488-489] says regarding the purloined letter: "As soon as the narrator makes Dupin return his letters, and not only to the Queen (the other Queen), the letter divides itself, is no longer atomistic ... and therefore loses any certain destination." This is of course related to the analysis of Derrida [56] of consciousness and language. In every instance of self-reflection, speaking or writing, the self separates itself from itself by the use of signs (marks). The functioning of marks is furthermore made possible by their iterability-their capacity to function in the absence (also in the event of death) of the speaker/writer/addressee.
} 
sent and return to the unconscious formed by the Oedipus complex; $3^{6}$ the letter always arrives at its destination; it comes back to where it should be; thus returning to a true origin [38, p. 92 n. 47 (translator's note)].

In Derrida's reading, the phallus, which is central to Lacan's model, is displaced. In Lacan, it is castration-truth (the letter being found by Dupin in the Minister's office on the card rack, "[b]etween the jambs of the fire-place") 37 which contracts itself "in order to bring the phallus, the signifier, the letter, or the fetish back into their oikos, their familiar dwelling, their proper place" [2, pp. 441, 442, 446; 4, p. 26]. Derrida agrees with Lacan that 'man' and 'woman' may be subject to phallogocentrism and that the phallus as Freud pointed out is primary or that the libido is masculine in nature [2, pp. 480, $481 \mathrm{n} .60,482]$. This characteristic can be equated with reason [2, p. 482]. Derrida nevertheless takes issue with Lacan's attempt to install the phallus as the primary signifier through his reading of the Oedipus complex. There is no necessity for this interpretation Derrida (at 477 n. 56, 481 n. 60) points out, based as it is on an individual, perceptual, local, cultural, historical situation (including the sexual theory of a little boy). This sexual theory is furthermore based on a "phase of the male child's experience" (which Derrida [2, p. 481 n. 6o] does not question in itself). As Derrida argues, phallogocentrism has not simply been an accident in Western thinking. This does not, however, mean that it should be continued as an ethical, institutional and political practice as Lacan seeks to do in the Seminar [2, p. $481 \mathrm{n}$. 60]. Derrida's phrase 'band erect' instead of 'to be' shows the different relation in his thinking to the phallus and to reason [49, pp. 22b-23b, 133b]. The phallus and thus also reason or mastery are not 'erected' firstly because of the function of the pleasure principle in the psyche, but through the binding of the death drive, first by the primary process $[2, \mathrm{p} .394] .3^{8}$ The play of castration is in turn related to the death drive, dissemination or the hymen [38, p. 71].39

Dissemination, as Derrida points out, escapes from, disorganises and 'un-sews' Lacan's symbolic order, makes it drift, without being caught within the orders of the imaginary or the real [38, p. 70]. The displacement of the phallus in Derrida's reading has important consequences seeing that it (the phallus) is related to the sacred, life, immunity, health, fertility, growth, swelling, the strong, the powerful, sovereignty, pregnancy (the spontaneously swollen or pregnant belly) and safety [68, p. 16; 69, par 39 read with n. 30]. The phallus presents itself as a surplus of life, as being able to live on after life and in defiance of death, as that which is most productive of life and most able to protect or indemnify life [68, p. 15]. The law of iterability (which Derrida

\footnotetext{
${ }^{36}$ According to Lacan [4, pp. 75-81, 671-702] 'the animal' does not have an unconscious and also does not have access to the symbolic order; see in this respect Derrida [2, p. $474 \mathrm{fn} \mathrm{51]} \mathrm{and} \mathrm{Derrida} \mathrm{[52].} \mathrm{Derrida's} \mathrm{'notions'} \mathrm{of}$ différance, posts and envois, do not await language, and more specifically, not human language; see Derrida [2, p. 66].

37 This placement of the letter in Bonaparte's and Lacan's readings refers to fetishism or the process of (the Minister) rephallicizing the mother; see Derrida [2, pp. 445-447].

${ }^{38}$ See also Derrida [2, p. 396] where he refers to Freud's discussion of the sexual act where binding (erection) takes place in service of the pleasure of discharge or final relaxation (not, however as yet final orgasm or pleasure without end (at 397).

${ }^{39}$ See also Derrida [38, p. 71] on the relation between the death drive and dissemination.
} 
explores in his analysis of speech and writing) or of duplication however detaches it (the phallus) from its pure and proper presence. The erection of the phallus in other words gives the impression of life, but its machinelike, reflex or mechanical character also separates it from the life it represents. The phallus can thus be detached from its pure and proper presence, turning it into a ghost, spectre, double or fetish [69, par 39]. This is somewhat similar to what happens in festivals where the phallus is turned into a (detached) fetish. Instead of simple pure presence there is life death, sur-vival, resuscitation [69, par 39].

We can also now better understand how Derrida could agree with Lacan that The Purloined Letter relates to the repetition compulsion, yet offer a markedly different reading. In exploring the notion of repetition Derrida refers first to the classical notion of repetition which would entail the repetition of an original or something primary [2, pp. 351-352]. This is how Lacan and Freud understand narration in their reading of fiction-as a repetition of something that exists beforehand and which would therefore also have a signified and a referent-here the Oedipus complex or the phallus/castration. Repetition would be secondary or derivative. For Derrida, as we saw in the discussion above, repetition is 'pre-originary'. As he puts it elsewhere, life (death being at its pre-origin) "can defend itself against death only through an economy of death, through deferment, repetition, reserve" [48, p. 254].The following passage makes the 'pre-originary' function of the repetition clear [48, p. 254]:

[I]n the first time of the contact between two forces [referring to death and life], repetition has begun. Life is already threatened by the origin of the memory which constitutes it, and by the breaching which it resists, the effraction which it can contain only by repeating it.

Repetition, as we furthermore saw, takes place within the zone of ('preoriginary') différance [48, p. 255]. In other words, repetition takes place in the zone between the primary and secondary processes. The Purloined Letter would therefore not entail the repetition of something original (for example the Oedipus complex), but a preoriginary repetition which takes place in the zone of différance.

\section{Implications}

It should now be clear that Derrida's reading of The Purloined Letter is not simply one which seeks to impose thereon a different interpretation than that of Lacan. Derrida's reading could be said to seek to bring out that which conditions a sending such as The Purloined Letter, not simply with reference to the Oedipal unconscious, but with reference to that which precedes as 'pre-origin' any possible Oedipus complex; in other words, framing, the double or dissemination. We saw in Derrida's reading of Freud's Beyond the Pleasure Principle how the latter 'notions' are all related to the death drive which is at work in all organisms, organisations and institutions. As will be indicated briefly below, this holds significant implications for constitutional interpretation. If we follow Lacan's hermeneutic approach of the 
unconscious as portrayed in the Seminar, we are not confronted with dissemination, fragmentation without return or what would later be referred to by Derrida as justice [70]. Lacan's Seminar remains tied to speech, origin, truth, presence and meaning and thus to a restricted economy involving a circular return to the same [2, pp. 425, 437, 441]. As we saw, Derrida's exposition of the death drive, which finds expression through the frame and the double, escapes and disorganises the Lacanian symbolic order and is a 'law' that must be followed in every reading of texts.

Insofar as the text of a constitution is concerned, a number of similarities with The Purloined Letter appear. It can be said to be 'sent' in a similar way as The Purloined Letter and to have a similar structure as that text, the latter in turn corresponding with the life-death stricture described above [24, p. 171]. As Derrida makes clear in Declarations of Independence (with its related themes of writing, representation, the proper name and the signature), and also in Force of Law, a constitution's condition of possibility is not to be found in anything outside the text such as the people or God which provide a stable point of reference for interpretation [35, 70]. These attempted stabilisers of meaning are themselves placed on-stage in the text (as happens also with the narrator in The Purloined Letter), usually in the preamble of a constitution, thereby setting them adrift. A constitution, in its preamble, also typically, like The Purloined Letter, begins by referring back to other (textual) events and to other texts (such as preceding constitutions, the constitutions of other countries and international treaties) which precede the adoption of the constitution. The repetition that is at stake in a constitution is not however of something original, but as explained above in the context of the death drive, an originary repetition taking place in the zone of différance. If we furthermore follow Austin, as Derrida does, in stating that only a sentence has meaning, the title of a constitution-which invariably is not a sentence-can similarly be said to overflow the constitution, opening it to meaninglessness, dissemination, or a general economy [71, pp. 112-115]. Some of the substantive provisions of a constitution such as those providing for fundamental rights, if read in the manner proposed by Derrida, also include in a way similar to the luxury of books, meditation and meerschaum in The Purloined Letter, that which goes beyond a strict economy, like a gift without exchange.40

To the hermeneut who is concerned only with meaning, the above analysis will be of little relevance. If account is however taken of this textual drift, a constitution, similar to The Purloined Letter, can be said to be written as an expression of a desire for or drive towards death or absolute pleasure or what can also be referred to as justice. 41 As Derrida [70] furthermore spells out in Force of Law, an interpreter of a constitution (whether written or unwritten) is 'confronted' not simply by a text which can be interpreted in various (reasonable) ways, but firstly by the demand or promise inscribed in each constitution for unconditional justice as pre-origin [73, pp. 21-22, $67-68,73]$. Justice calls for the expropriation of the proper, of property, of restricted

\footnotetext{
${ }^{40}$ See Derrida [72, pp. 42-55] on immeasurable equality.

${ }^{41}$ See Derrida [70, p. 14] on the mystical foundation of authority.
} 
economy, of rights, of law, of reason, and of meaning. It calls for "a rending decision as the decision of the other. Of the absolute other in me, the other as the absolute that decides on me in me" [37, p. 68; 70, pp. 26-28]. This is an intrinsic part of every interpretation of a constitution [70, p. 37]. Interpretation which is only hermeneuticsemantic in nature excludes or neutralises the double law of a constitution in an attempt to avoid uncontrollable anxiety. It is furthermore based on the flawed belief that a constitution imposes only a strict economy and thus always returns to its sender. This makes of constitutional interpretation simply a circular and selflegitimating activity which remains caught-even in progressive versions thereofwithin the trappings of democratic constitutionalism [72, pp. 6-18]. A break with constitutional democracy understood as ipseity or auto-affection is possible only if account is taken of Derrida's approach to reading in The Purveyor of Truth.

Acknowledgement: The author would like to acknowledge the generous funding provided for the research by the Alexander von Humboldt Foundation.

\section{References}

1. Derrida, Jacques. 2007. Psyche: Inventions of the other, Vol. 1. Stanford: Stanford University Press.

2. Derrida, Jacques. 1987. The post card: From Socrates to Freud and beyond. Chicago and London: The University of Chicago Press.

3. Derrida, Jacques. 1999. The purveyor of truth. Yale French Studies 96: 124-197.

4. Lacan, Jacques. 2006. Écrits. New York and London: WW Norton \& Company.

5. Poe, Edgar Allan. 1985. The complete tales \& poems of Edgar Allan Poe. Castle.

6. Johnson, Barbara. 1977. The Frame of reference: Poe, Lacan, Derrida. Yale French Studies 55/56: 457-505.

7. Gallop, Jane. 1985. Reading Lacan. Ithaca and London: Cornell University Press.

8. Irwin, John T. 1986. Mysteries we reread, mysteries of rereading: Poe, Borges, and the analytic detective story; also Lacan, Derrida and Johnson. MLN 101: 1168-1215.

9. Harvey, Irene. 1988. Structures of exemplarity in Poe, Freud, Lacan, and Derrida. In The purloined Poe, ed. John P. Muller and William J. Richardson, 252-267. Baltimore and London: John Hopkins University Press.

10. Gallop, Jane. 1988. The American other. In The purloined Poe, ed. John P. Muller and William J. Richardson, 268-282. Baltimore and London: John Hopkins University Press.

11. Schneiderman, Stuart. 1991. Fictions. In Lacan and the subject of language, ed. Ellie Ragland-Sullivan and Mark Bracher, 152-166. New York and London: Routledge.

12. Stockholder, Kay. 2000. Is anybody at home in the text? Psychoanalysis and the question of Poe. American Imago 57: 299-334.

13. Ellmann, Maud. 2000. Deconstruction and psychoanalysis. In Deconstructions: A user's guide, ed. Nicholas Royle, 211-237. New York: Palgrave. 
14. Sucur, Slobodan. 2001. Poe, Odoyevski, and purloined letters. European University Studies Series XVIII comparative literature. Vol. 99. Frankfurt am Main: Peter Lang.

15. Žižek, Slavoj. 2001. Enjoy your symptom!: Jacques Lacan in Hollywood and out. New York and London: Routledge.

16. Pankow, Edgar. 2002. Brieflichkeit: Revolutionen eines Sprachbildes - Jacques Louis David, Friedrich Hölderlin, Jean Paul, Edgar Allan Poe. München: Wilhelm Fink Verlag.

17. Caudill, David S. 1992. Lacan and legal language: Meanings in the gaps, gaps in the meaning. Law and Critique 3: 169-210.

18. Caudill, David S. 1997. Lacan and the subject of law: Toward a psychoanalytic critical legal theory. New Jersey: Humanities Press.

19. Collins, Barry. 2002. The Belfast agreement, the purloined letter and the 'politics of the ostrich'. International Journal for the Semiotics of Law 15: 273-292.

20. Cornell, Drucilla. 1990. The doubly-prized world: Myth, allegory and the feminine. Cornell Law Review 75: 644-699.

21. Cornell, Drucilla. 1995. Law and the postmodern mind: Rethinking the beyond of the real. Cardozo Law Review 16: 729-792.

22. Norris, Christopher. 1987. Derrida. Cambridge, Massachusetts: Harvard University Press.

23. Major, Rene'. 2001. Derrida and psychoanalysis: Desistantial psychoanalysis. In Jacques Derrida and the humanities: A critical reader, ed. Tom Cohen, 269-314. Cambridge: Cambridge University Press.

24. Hobson, Marian. 1998. Jacques Derrida: Opening lines. London: Routledge.

25. Michelman, Frank I. 1998. Constitutional authorship. In Constitutionalism: Philosophical foundations, ed. Larry Alexander, 64-98. Cambridge: Cambridge University Press.

26. Habermas, Jürgen. 2001. Constitutional democracy: A paradoxical union of contradictory principles? Political Theory 29: 766-781.

27. Schuppert, Gunnar Folke. 2003. Staatswissenschaft. Baden-Baden: Nomos Verlagsgesellschaft.

28. Du Plessis, Lourens. 2005. The (re-)systematization of the canons of and aids to statutory interpretation. South African Law Journal 122: 591-613.

29. Schank, Peter C. 1992. Understanding postmodern thought and its implications for statutory interpretation. Southern California Law Review 65: 2505-2597.

30. Feldman, Stephen M. 1996. The politics of postmodern jurisprudence. Michigan Law Review 95: 166-202.

31. Cornell, Drucilla. 1992. The philosophy of the limit. New York: Routledge.

32. Minkkinen, Panu. 1999. Thinking without desire: A first philosophy of law. Oxford: Hart Publishing.

33. Douzinas, Costas. 2000. The end of human rights. Oxford: Hart Publishing.

34. Fitzpatrick, Peter. 2000. Modernism and the grounds of law. Cambridge: Cambridge University Press.

35. Derrida, Jacques. 2002. Negotiations: Interventions and interviews 1971-2001. Stanford: Stanford University Press. 
36. Derrida, Jacques. 1987. The truth in painting. Chicago and London: University of Chicago Press.

37. Derrida, Jacques. 1997. Politics of friendship. London and New York: Verso.

38. Derrida, Jacques. 2002. Positions. London and New York: Continuum.

39. Bonaparte, Marie. 1971. The life and works of Edgar Allan Poe: A psychoanalytic interpretation. New York: Humanities Press.

40. Bonaparte, Marie. 1988. The life and works of Edgar Allan Poe: A psycho-analytic interpretation (partially reprinted). In The purloined Poe, eds. John P. Muller and William J. Richardson, 101-132. Baltimore and London: John Hopkins University Press.

41. Derrida, Jacques, and Elisabeth Roudinesco. 2004. For what tomorrow...a dialogue. Stanford: Stanford University Press.

42. Freud, Sigmund. 2001. The standard edition of the complete psychological works of Sigmund Freud. Volume XVIII (1920-1922). London: Vintage.

43. Staton, Shirley F. ed. 1987. Literary theories in praxis. Philadelphia: The University of Pennsylvania Press.

44. Derrida, Jacques. 1998. Resistances of psychoanalysis. Stanford: Stanford University Press.

45. Muller, John P. and William J. Richardson. 1988. Lacan's seminar on 'the purloined letter'. In The purloined Poe, ed. John P. Muller and William J. Richardson, 55-76. Baltimore and London: John Hopkins University Press.

46. Ragland-Sullivan, Ellie. 1986. Jacques Lacan and the philosophy of psychoanalysis. Urbana and Chicago: University of Illinois Press.

47. Derrida, Jacques. 1984. My Chances/Mes Chances: A rendezvous with some epicurean stereophonies. In Taking chances: Derrida, psychoanalysis, and literature, ed. Joseph $\mathrm{H}$. Smith and William Kerrigan, 1-32. Baltimore and London: John Hopkins University Press.

48. Derrida, Jacques. 2001. Writing and difference. London and New York: Routledge.

49. Derrida, Jacques. 1986. Glas. Lincoln and London: University of Nebraska Press.

50. Freud, Sigmund. 2001. The standard edition of the complete psychological works of Sigmund Freud. Volume XVII (1917-1919). London: Vintage.

51. Derrida, Jacques. 2004. Dissemination. London and New York: Continuum.

52. Derrida, Jacques. 2003. And say the animal responded? In Zoontologies: The question of the animal, ed. Cary Wolfe, 121-146. Minneapolis and London: University of Minnesota Press.

53. Derrida, Jacques. 1995. Archive fever: A Freudian impression. Chicago and London: The University of Chicago Press.

54. Derrida, Jacques. 1986. Foreword: Fors: The Anglish words of Nicholas Abraham and Maria Torok. In The wolf man's magic word: A cryptonomy, ed. Nicholas Abraham and Maria Torok, xi-xlviii. Minneapolis: University of Minnesota Press.

55. Derrida, Jacques. 1976. Of grammatology. Baltimore and London: The John Hopkins University Press.

56. Derrida, Jacques. 1973. Speech and phenomena and other essays on Husserl's theory of signs. Evanston: Northwestern University Press. 
57. Derrida, Jacques. 1988. Limited Inc. Evanston: Northwestern University Press.

58. Derrida, Jacques. 2000. Demeure: Fiction and testimony. Stanford: Stanford University Press.

59. Derrida, Jacques. 1994. Specters of Marx: The state of debt, the work of mourning, \& the new international. New York and London: Routledge.

60. Freud, Sigmund. 2001. The standard edition of the complete psychological works of Sigmund Freud. Volume XIV (1914-1916). London: Vintage.

61. Clough, Patricia Ticineto. 2000. The technical substrates of unconscious memory: Rereading Derrida's Freud in the age of teletechnology. Sociological Theory 18: 383398.

62. Derrida, Jacques. 1992. Given time: I. Counterfeit money. Chicago and London: University of Chicago Press.

63. Lacan, Jacques. 1992. The ethics of psychoanalysis 1959-1960: The seminar of Jacques Lacan: Book VII. London and New York: Routledge.

64. Žižek, Slavoj. 2006. A plea for a return to Différance (with a Minor Pro Domo Sua). Critical Inquiry 32: 226-249.

65. Douzinas, Costas. 2007. Human rights and empire: The political philosophy of cosmopolitanism. London and New York: Routledge-Cavendish.

66. Derrida, Jacques. 1995. Points...interviews, 1974-1994. Stanford: Stanford University Press.

67. Derrida, Jacques. 2003. Following theory. In Life after theory, ed. Michael Payne, John Schad, 1-51. London and New York: Continuum.

68. Naas, Michael. 2007. Comme si, comme ça: Phantasms of self, state, and a sovereign God. Mosaic 40: 1-26.

69. Derrida, Jacques. 1998. Faith and knowledge: The two sources of 'religion' at the limits of reason alone. In Religion, ed. Jacques Derrida and Gianni Vattimo, 1-78. Stanford: Stanford University Press.

70. Derrida, Jacques. 1992. Force of law: The 'mystical foundation of authority'. In Deconstruction and the possibility of justice, ed. Drucilla Cornell, Michel Rosenfeld, David Gray Carlson, 3-67. New York and London: Routledge.

71. Derrida, Jacques. 1986, 1989. Memoires for Paul de Man. New York: Columbia University Press.

72. Derrida, Jacques. 2005. Rogues: Two essays on reason. Stanford: Stanford University Press.

73. Derrida, Jacques. 1998. Monolingualism of the other; or, the prosthesis of origin. Stanford: Stanford University Press. 